\title{
Factors Influencing Consumer Choice of Brands of Custard in Enugu State
}

\author{
Okoro, Deborah $\mathbf{P}^{1}$, Mmamel, Zita $\mathbf{U}^{2}$, Okolo, Victor $\mathbf{O}^{1^{*}}$ \\ ${ }^{I}$ Department of Marketing, University of Nigeria Nsukka, Enugu Campus \\ ${ }^{2}$ Department of Marketing, Institute of Management and Technology, Enugu
}

*Corresponding Author: Okolo, Victor O, Department of Marketing, University of Nigeria Nsukka, Enugu Campus

\begin{abstract}
This study sought to examine consumer choice of brands of custard in Enugu State. Specifically, the study firstly examined the extent to which price affects consumer choice of brands of custard in Enugu State. It secondly ascertained the influence of packaging on consumer choice of brands of custard in Enugu State. It finally examined the effect of advertising on consumer choice of brands of custard in Enugu State. Descriptive research design was adopted for the study while the consumers (adults 18 years and above) were the target the population. A sample size of 323 was used for the study while questionnaire was used for data collection. Three hypotheses were tested using linear regression and Pearson product moment correlation coefficient. Findings revealed that price had a significant positive effect on consumer choice of brands of custard. Similarly, packaging had a significant positive influence on consumer choice of brands of custard. Finally, advertising had a significant effect on consumer choice of brands of custard. The study concluded that there is a significant relationship between price, packaging and advertising, and consumer choice of custard brands in Enugu State. The study recommends that manufacturers should reduce the price of custard to make it more affordable for consumers. Also, custard should be packaged in smaller sachet to offer consumer more choices during purchase and finally, advertising campaign should be boosted to create more consumer awareness about the value of consuming custard.
\end{abstract}

Keywords: Consumer Buying Behaviour, Custard, Price, Packaging, Advertising, Brand.

\section{INTRODUCTION}

In this era where consumer is the king in every market transaction, the study of consumer behaviour has become essential as no business can be said to be successful without consumer patronage (Brosekhan \& Velayutham, 2013). In the struggle for profitable survival, the manufacturer looks outwards at the consumers rather than inwards at his production processes and capacity. However, when studying the consumer, one must consider both the economic circumstances and the demographic character of the individual and the more powerful influences of prejudices, feelings, attitudes, opinions and beliefs (Modi \& Jhulka, 2012).

Nowadays companies are more concerned with individual consumer behaviour. It helps them to yield information about how the consumers think, feel and choose their products. Consumer behavior is the study of the processes involved when individual or groups select, purchase, use, or dispose of the product, service, ideas or experiences to satisfy needs and desires (Solomon, 1998). The deliberate view of the consumer embraces much more than the study of why and what he or she buys, but also focuses on how the marketer influences the consumer and how they use the products and services.

Kotler \& Solomon (2003; Marshall \& Stuart, 2008), define consumer buying behaviour as the understanding of a process that a group or an individual passes through to satisfy a need, by making preference and buying as well as utilizing and disposing of products. Similarly, ideas and experience can be involved in the process to satisfy a need. In the same vein, Solomon (1996) opines that consumer buying behaviour means the integral process of decision-making and also the activity of people engaging in selecting, purchasing, consuming and disposing of products. It also involves responses such as behavioural, mental and emotional which describe and follow these activities. 
Consumer buying behaviour does not involve only the purchasing of a product; it is also an extensive and complex process from the beginning to the end of marketing process. According to Khan (2004), the first step to consumer buying behaviour begins with the mind of the consumer who recognizes the need, explores new information related options and variety of choices and then defines the benefits of various alternatives. Finally, the process ends up in deciding on the products to be purchased and the actual buying. Customer satisfaction can be realized at a post-stage purchase after the actual purchase giving a vital signal to the seller. Surrounding consumer buying behaviour are many factors which affect the manner in which consumers act and take decision during the purchasing process (Domie, 2013). Modi \& Jhulka (2012) opine that consumer buying behaviour is a subset of human behaviour because several internal and external factors affecting individuals in their daily lives also influence their purchase activities. Hawkins, Best \& Coney (1998), observe that consumer buying behaviour could be affected by external and internal factors such as culture, subculture, demographics, social status, references group, family and aspects. Also, marketing activities such as perception, learning, memory, motives, personality, emotion and attitudes are seen as internal factors (Kotler, Armstrong \& Opresnik, 2018).

Consumer choice is very important in marketing of a given product and must be taken into seriously for any business to succeed. According to Aaker (1991), consumers are indifferent to a brand and they in fact buy with respect to the features, price and convenience with little concern to the brand name. Fredrick (1990) states that making product available at all times so that the customer has a choice is one of the very important marketing strategies a manufacturer can use and can help achieve unique competitive advantage. To provide satisfaction to the consumers, marketers must understand how all their marketing activities are perceived because perceptions greatly influence consumer choice of a product or service. Consumer choice ofa product which is a bundle of attributes is based on maximizing satisfaction to his budget constraints of available resources. The choice depends on whether the consumer is satisfied or dissatisfied with the product. Quite similarly, consumer choice can also be approached from the perspective of conscious and non-conscious choice (Blackwell, 2006). Kivetz, \& Simonson (2000), observe that many choice situations occur outside of conscious awareness and with information search.

Custard is a finely textured food product manufactured from corn starch in which salt, flavouring and colouring agents are added with or without the addition of egg yolk, solid vitamins and minerals (Okoye, Nkwocha \& Agbo 2008). Understanding consumer buying behaviour will help manufacturers to know consumers expectations when they buy products and so tailor their products to meet these expectations.

\subsection{Statement of the Problem}

One of the fastest growing food related industries in Nigeria is custard (Sinebe, Okonkwo \& Enyi, 2014). Its consumption has penetrated every nook and cranny of Nigerian household. Marketers of the product are faced with meeting the demand and satisfaction of their various customers amid stiff competition. The cost of production is rising as sales continue to fall while consumers demand high quality custard (Sinebe et al., 2014). Consumers are very interested and attracted to goods and services because of the characteristics or quality they possess. However, consumers are worried over the price, packaging and advertisement of different brands of custard available in the market. The prices of custards are high, the packaging only come in containers and marketers have not fully used advertisement to convey information about different brands to allow consumer choice of the products in the market. As a result of these challenges, the researcher investigated factors influencing consumer choice of brands of custard in Enugu State.

\subsection{Objectives of the Study}

The main objective of this study is to examine consumer choice of brands of custard in Enugu State. The specific objectives include the following:

- To examine the extent to which price affects consumer choice of brands of custard in Enugu State.

- To ascertain the influence of packaging on consumer choice of brands of custard in Enugu State.

- To examine whether advertising affects consumer choice of brands of custard in Enugu State. 


\subsection{Research Questions}

Based on the statement of the problem and objectives of the study, the study seeks to answer the following research questions:

- To what extent does price affect consumer choice of brands of custard in Enugu State?

- To what extent does packaging influence consumer choice of brands of custard in Enugu State?

- How does advertising affect consumer choice of brands of custard in Enugu State?

\subsection{Research Hypotheses}

In line with the objectives of the study and research questions, the following null hypotheses were formulated.

- Price does not have a significant effect on consumer choice of brands of custard in Enugu State

- Packaging has no significant influence on consumer choice of brands of custard in Enugu State

- Advertising does not have a significant effect on consumer choice of brands of custard in Enugu State

\subsection{Significance of the Study}

The outcome of this research work will be useful to manufacturers of custard brands. The findings will help manufacturers to assess those factors that affect consumer choice toward their brands and the best way to address those factors. Consumers of custard brands will equally benefit from the outcome of this study. The study will serve as a reference material to researchers and the academia.

\subsection{Scope of the Study}

The scope of this study borders on pricing, packaging and advertising which are the factors influencing of consumer choice of brands of custard. This study was conducted in Enugu State.

\section{REVIEW OF THE RELATED LITERATURE}

This chapter explores the literature related to consumer choice of brands of custard in Enugu Metropolis.

\subsection{Concept of Consumer Buying Behaviour}

Consumer buying behaviour is the attitude which every consumer exhibits about product attributes before making any purchase. Consumer behaviour is the understanding of a process that an individual or a group passes through to satisfy a need by making preferences and buying as well as utilizing and disposing of products (Solomon et al., 2008). In their contribution, Kotler et al. (2018) see consumer behaviour as mental, physical and emotional engagement that people use during purchase, selection, use and dispose of services and products that satisfy their desires and needs. It is a discipline that borrowed heavily from concepts developed in other fields such as psychology (the study of the individual), social psychology (the study of how an individual operates in groups), sociology (the study of groups), anthropology (the influence of society on the individual), and economics. However, Oni \& Bananda (2010) opine that consumer buying behaviour is the way people act in the exchange process, this process can further see as stages of the decision process customers go through. This process includes problem recognition, alternative evaluation, information search, actual purchase and post-purchase evaluation (Kotler \& Arnstrong, 2012). Buyer behaviour particularly is the study of decision-making units as they can buy for others or themselves. Thus, buying behaviour mainly involves the collective response of customers for selecting, evaluating, deciding and post-purchase behaviour. It is the study of human response to services and the marketing of products and services.

According to Dawson, Findlay \& Sparks (2006), consumer buying behaviour is a set of attitudes that characterized the patterns of consumers' choices. Solomon (1996) observe that consumer buying behaviour means the primary process of decision making and also an activity of people engaging in selecting, purchasing, consuming and disposing of products. This process also involves responses such as behavioural, mental and emotional which describe and follow these activities. According to Adede et al. (2016), it becomes very difficult for a marketer to predict the products that consumers 
may consider to buy as well as the quantities to be purchased at a given time. Moreover, marketers are not able to know with certainty why consumers choose particular brands and disregard others.

\subsubsection{The Product: Custard}

Custard is a fine textured food product made from corn starch in which salt, flavouring and colouring agents are added with or without the addition of egg yolk solids, vitamins and minerals (Okoye, Nkwocha \& Agbo, 2008). The cornstarch used for the preparation of custard is basically dense, powdery flour obtained from the endosperm protein of the corn kernel. Custard is primarily consumed either as a breakfast cereal-based food or weaning food in most developing nations of the tropics especially among children (Ihekoronye \& Ngoddy, 1985). Since custard is mainly rich in carbohydrate, there is need to improve the nutritional status of the product by the addition of vegetable proteins from oilseeds and legumes such as cowpea, soybean and pigeon pea etc, which are relatively cheap and readily available. The fortification of custard with vegetable proteins from oilseeds and legumes has received considerable attention. This is because oilseed and legume proteins are high in lysine, an essential limiting amino acid in most cereals (Enwere, 1998). Legumes which generally contain a relatively high amount of protein should complement the protein in cereal grains because the chemical and nutritional characteristics of legumes make them natural complements to cereal-based diets (Marero et al, 1988).

Brands of custard include the following: Gold's (vanilla), Arise daily best (Banana best), Anno best, Family custard, Infinity custard, Birds custard, City joy custard, Checkers custard powder etc.

\subsubsection{Consumers and Influencing Factors}

Surrounding consumer behaviours are many influencing factors which affect the manner customers reason and act during the purchasing process (Domie, 2013). The factors include social, cultural, personal and psychological factors which persuade the consumer buying behaviour. Careful examination of these factors encourages many firms to attain their objectives by gaining control over the domestic market (Kardes, Cronley \& Cline 2008). Culture refers to the set of values, ideas and attitudes that are acceptable by a homogenous group of people and transmitted to the next generation (Jibril, Fudamu \& Tumba 2013). Culture is the essential character of a society that distinguishes it from other cultural groups. The underlying elements in every culture are the values language, myths, customs, rituals, laws, artefacts or products that are transferred from a present generation to the next (Lamb, Hair \& Daniel,2011). Social factors play a significant role in influencing the buying behaviour of consumers. Several social factors affect consumer behaviour which comprises of the family, references group, status and social roles (Domie, 2013).

Personality refers to the particular psychological characteristics that lead to relatively consistent and lasting responses to one's environment. The personality factors include age, life cycle, economic and occupational conditions. As people grow their desires and need change. Psychological factor refers to the emotional disposition of consumers as he or she embarks on the purchase of goods and services (Durmaz, 2014). The psychological factors that influence an individual's decisions to make a purchase are categorised into the person's motivations, perceptions, learning and his beliefs and attitudes (Callwood, 2013).

\subsubsection{Price}

Price refers to the amount of money that a person must pay to use a product. To set a price for a product requires a thorough understanding of the symbolic role that price plays in determining the products in the target market ( Gilaninia, Taleghani \& Azizi, 2013).

However, according to Alex \& Menon (2013), price-conscious consumers by definition like to purchase products which are priced low and hence they would have a tendency to compare prices before making the purchase decision. Price is categorically one of the most important market variables. It becomes necessary that there are many ways of price framing. Price framing is defined as how the offered price is communicated to the consumers ( Briesch, Krishna, Lehman \& Yuan, 2002). Framing the same information in a variety of ways can have a great impact on consumer decision making and choice behaviour. The survival of any business firm depends on its pricing strategy since the price is highly critical in the implementation of marketing tactics. (Domie, 2013). In the keen competitive environment, the price is used as a medium to obtain an upper hand over competitors. 
According to Bondari (2010), price provides the base for customers to search for their suitable products that are within a particular price category ignoring those that are not part of it. Cook \& Marthur (2008) explain that consumers have become highly mobile and are searching for values in return for the money spent with additional advantages and benefits.

In most cases, if a customer does not appreciate a quoted price for a product, there wouldn't be any purchase, and this has an adverse impact on the sales and the market share in the long run. Lindsay \& Evans (2011), also argue in the same regard that in a competitive market, firms must seek to consider satisfying consumer needs at lower prices and this helps the company to a obtain a competitive edge.

\subsubsection{Packaging}

In marketing's dynamic competitive environment, the role of a package has changed due to increased self-service and changing consumer lifestyle. Firms' interest in the package as a tool for sales advertising is growing increasingly. Packaging becomes an ultimate selling proposition stimulating impulsive buying behaviour, increasing market share and reducing advertisingal cost (Deliya \& Parmar, 2013). Shah, Ahmad \& Ahmad (2013) observe that packaging is the essential element and container of the product that protects and beautifies a product to gain customer attraction and attention. Packaging according to Kunle \& Ganiyu (2012) has become a potent marketing tool, and its role has changed from the traditional function of protecting the products through distribution channels against damage, dirt, theft, mishandling and deterioration. This functional role is a fundamental requirement of packaging.

In this modern era, packaging is also utilized as a marketing tool to arouse and stimulate consumer's attention and to promote and convey relevant messages about products' features to customers while still on the shelf or at the point of sale. However, Raban (2010) describes packaging as a coordinated system that prepares well for transportation, distribution, storage, sale and consumption and tool for ensuring product safety in delivery to the ultimate consumer in best of circumstances, with the lowest average cost. The packaging of a product entails designing and constructing the container or wrapper for a product (Ladipo \& Olufayo, 2011). Ahmed et al. (2014) observe that packaging elements includes colour, packaging material, design of wrapper and innovation .The wrapper and container may take account of the product's primary container, a less substantial package, that is disposed of when the product is about to be used and shipping package necessary to store, identify and ship the product (Ladipo \& Olufayo, 2011). Other parts of packaging include labeling and printed information appearing on or with the package. The key packaging materials are paper/fiberboard, plastic, glass, steel, aluminum, etc. While packaging colour, printed information, packaging material, the design of wrapper, background image and innovation influence consumer buying behaviour (Shah et al., 2013).

\subsubsection{Advertising}

Advertising is non-personal messages paid for by an identified sponsor and conveyed to the consumers through the media of communication about available goods and services (Kotler, Armstrong \& Opresnik, 2018). It is one of the major tentacles of marketing communication which is as old as man (Okolo, Mmamel, Nmere, Nduka, Obikeze \& Oranusi, 2018). It is used alongside public relations, publicity, direct marketing, personal selling and sales advertising to project a good image of a brand. It is the major marketing communication strategy used to inform, persuade and remind consumers about availability, location and prices of goods and services (Belch \& Belch, 2018). It is an aspect of marketing communication tool that is used by the retailers and manufacturers to create awareness and invite consumers to purchase goods and services. However, advertising has many media through which it sends messages to a target audience. The media of advertising include television, radio, newspaper, magazine, billboard (Abubakar, 2014) and the social media.

Advertising messages can boost sales volume, increase market share and bolster company and brand image (Abubakar, 2014). According to Abubakar, both sales and communication effect of a brand can be determined through advertising campaign. Zia \& Shahzad (2015) remark that advertising has a significant impact on sales of product. Abah \& Olohiliye (2015) reveal in a study on Benue Brewery Limited that a significant relationship exists between advertising and sales volume. Advertising messages are designed to align with the AIDA (Attention, Interest, Desire and Action) Model. That is, it must generate attention about the product or service, it must rouse consumer interest, it must bolster consumer desire and stimulate the purchase of a brand (Ugonna, Ndubisi, Otugo, Eze \& Akabogu, 2014). 


\subsubsection{Brand}

Brands are always considered as the best tool for marketing strategy. According to Doyle (2002), a brand is a specific name, symbol or design or more usually some combination of these that is used to distinguish a particular seller's product. A brand, in short, can be defined as a seller's promise to provide a unique set of characteristics, advantages and services consistently to the buyers/consumers. It is a name, term, sign, symbol or a combination of all these planned to differentiate the services or goods of one seller or group of sellers from those of competitors (Joshi, 2013). People in our society are so aware of their status and they prefer to use a branded product to show off their status. The brand name is an implied device through which any business can attain the attraction of the populace and can enjoy the competitive advantage (Malik, Ghafor, Igbal, Ali, Hunbal, Noman \& Ahmad, 2013).

The brand is also considered as a valuable asset for any business as it can change people's buying behaviour. Consumers rely on branded products and mostly prefer to buy products with the wellknown brand name. Marketing essential strategies and tools can develop the brand of any product. If a brand is superior, a business can enjoy a maximum number of customers and can build long-term profitable relations with customers. Khasawneh \& Hasouneh (2010) opine that customers realize the importance of brand while making their purchasing decision and consumers prefer the branded products with higher prices because they consider that branded items have more quality than nonbranded goods. Brand preference is also a mark of status. However, the important purchase cycle depends on 4p's, psychological factors like motivation, learning, perception, belief and attitude (Joshi, 2013).

\subsection{Theoretical Framework}

In this study, the theories of consumer behaviour as propounded by Nicosia (1966), Engel et al. (1968) and Howard \& Sheth (1969) will be relevant in examining the determinants of consumer choice of brands of custard. Nicosia (1966) provided a bold attempt to show the interrelationship between attributes of the consumer, the consumer decision-making process, the marketing communication of an organization and consumer feedback to the organization. However, the implication is that it is interactive in design, where the organization attempts to influence consumers through marketing actions/strategies and the consumers in return influence the organization through their purchase actions or lack of action if products are not purchased.

Engel et al. (1968) suggests that high involvement with a product results in a comprehensive problemsolving process which begins with problem recognition, information search, alternative evaluation, purchase and post-purchase activities. This provided a comprehensive discussion of the possible influences on consumer behaviour, and more specifically the impact of influences on the different stages of the decision-making process.

The Howard-Sheth model of buying behaviour, presents a robust integration of the psychological and various social and marketing influences on customer choice into a coherent sequence of information processing. The model attempts to explain typical brand choice behaviour within the constraints of incomplete information and limited individual capacities, and also that it provides an empirically testable description of conduct regarding cognitive functioning together with its outcomes. HowardSheth model is a model that explicitly distinguishes between three different stages or levels of decision-making or learning namely extensive, limited and routinized problem-solving.

However, in this study, the Howard-Sheth model of buying behaviour is adopted because it relates more to the topic under study, since it provides a sophisticated integration of the various social, psychological and marketing influences on consumer choice into a coherent sequence of information processing.

\subsection{Review of Empirical Studies}

Study conducted by Miebaka et al. (2017) on consumer behavioural pattern and patronage of made in Nigeria bags (A survey of bags producers in Rivers State, Nigeria) evaluated the reasons for consumer preference of made in Nigerian goods to foreign made goods (Bags). The study adopted the descriptive survey method as well as questionnaire method to enable consumers respond to their preference of either made in Nigeria goods (Bags) or foreign made bags. The study sample size of 120 
was drawn using non-probability sampling method (convenience) for generalization. Three hypotheses were stated and tested using person product moment correlation coefficient and the major findings revealed that there is a significant relationship between consumer behaviour pattern and patronage of made in Nigeria goods (Bags) in preference to foreign made goods (bags). It was therefore, recommended that producers should always carry-out constant research on the perception and behaviour pattern of consumers towards their product. Government of Nigeria should invest in markets that can boost their economy. Nigeria government should also protect the local bag companies by enacting favourable government policies.

In another study conducted by Ayuba (2014) in Nigeria titled, "assessment of factors influencing consumer satisfaction: a survey of customers of Nigerian manufacturing companies." The main objective of the study was to investigate the key variables having strong influence on customer satisfaction and the purchasing decisions of customers. Both primary and secondary methods of data collection were adopted for the study. The study consists of a population of 145 current and potential customers of the manufacturing companies listed on the Nigerian Stock Exchange (NSE) as at December 2013. The sample of the study is 100 selected based on stratified random sampling techniques. The data was analyzed using descriptive Statistics (mean, standard deviation) and regression analysis to assess the satisfaction-rating in line with the objectives of the study. The findings revealed that price is the primary factor influencing consumer buying behaviour in Nigeria. The results also showed that consumer experience with a particular brand changes the buying behaviour of consumers. The study concluded that three key variables namely; pricing dimension, product quality and consumer buying behaviour influences consumer satisfaction of manufacturers' products in Nigeria.

Also in a study conducted by Singh et al (2014) in India titled Factors Affecting Buying Behaviour of Rural Consumers. The objectives of the study includes to identify factors affecting buying decisions of rural consumers and to study the importance of identified factors affecting buying decisions of rural consumers by age and income of respondents. The sample of the study is 146 . Data was collected using questionnaire on five point scale. Frequency, mean and ANOVA were used to analyze the data. The findings revealed that rural consumer vary with age and income. The effect of price and quality on buying behaviour of rural consumer increases significantly with increase in age and income. Advertisement and brand of products found significantly very important to high income rural consumers than lower income consumers. Friends and family members' recommendations had significantly more impact on buying decisions of lower income consumers than high income consumers. Packaging had significantly more impact on buying decision of lower income consumers than high income. The study concludes by identifying eight factors i.e. price, quality, warranty, advertisement, brand, friends recommendations, family members recommendation and packaging which rural consumers consider while making purchase decisions consumers.

Daramola, Okafor \& Bello, (2012), conducted a study in Nigeria titled the Effect of Consumer Behaviour and Attitudinal Tendencies towards Purchase Decision (A Case Study Of Unilever Nigeria Plc,

Cadbury Nigeria Plc United African Companies Plc.). The study's main objective is to examine the effect of consumer behaviour and attitudinal tendencies towards purchase decision using Unilever Nigeria plc, Cadbury Nigeria plc, United African companies' plc as case studies. Other specific objectives includes to examine adequacy of factors usually considered in reaching the individuals and groups consumers; to measure the extent to which merits and demerits of individuals and groups consumers behaviour affect the marketer/producer; to establish incentives that could encourage consumption by the individuals and groups and to assess the effect of inability in providing information by the marketer/producer in reaching the individuals and groups at right time and place to fasten purchase on organizations goods and services. Questionnaire was used in collecting data while the sample size is 110 . The researcher used tables and percentages for presentation, scoring and analysis of data. The hypotheses were analyzed with the help of chi-square $\left(\mathrm{X}^{2}\right)$. The findings revealed that the life cycle in a product influence purchase to very much extent and that in some cases there is joint purchase decision in individuals and groups. Similarly the research discloses that education has a part towards determining purchase in any individual or group. The study concludes that management of firms should always carry out a thorough research on the effect of consumer income, educational level, occupational level, life style cycle, individually, or jointly decision that affect purchase behaviour. 
The gap noted in the previous literature which this study tends to fill is that no research of this nature has been conducted in Enugu State especially with the product custard. Hence this study centres on the factors influencing consumes choice of brands of custard in Enugu State.

\subsection{Proposed Conceptual Framework for the Study}

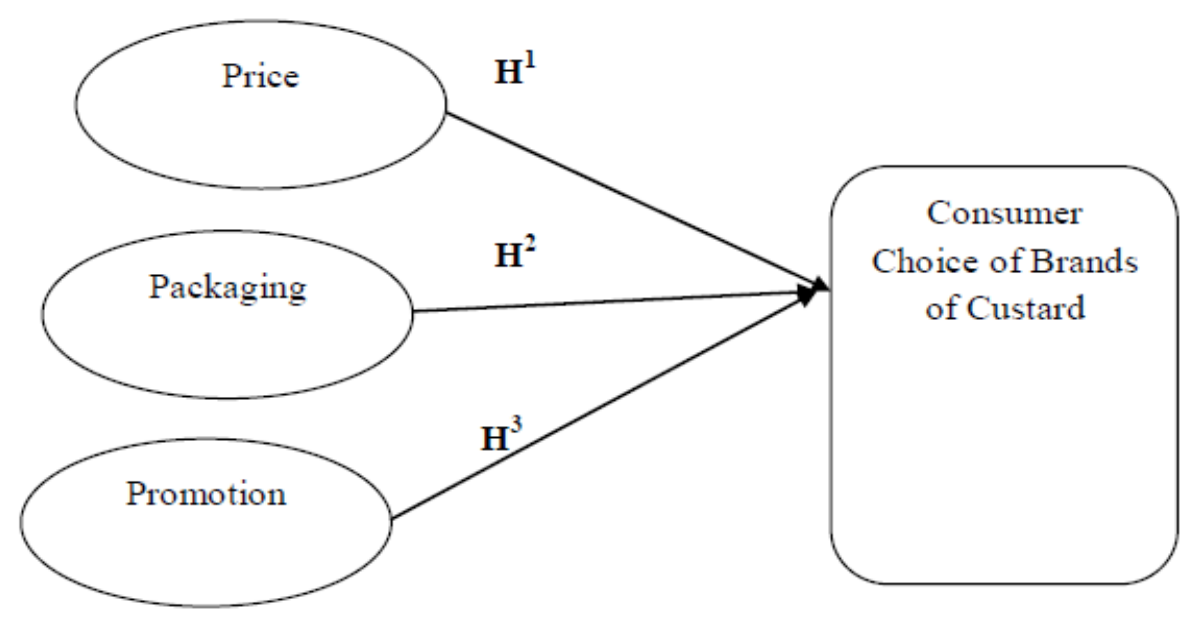

Proposed Conceptual Framework

Source: Researcher's Illustration

The diagram above presents the proposed conceptual framework showing the hypothesised factors influencing consumer choice of brands of custard in Enugu State.

\section{Methodology}

The study adopted a survey method; this was to enable the researcher to find facts by collecting information directly from the respondents. Data was collected through structured questionnaire and interview. The respondents were adults 18 years and above. It was observed from the preliminary study that out of ten copies of questionnaire distributed, 7 (or 70 per cent) answered positively while 3 (or 30 per cent) answered negatively. The sample size was 323 . The questionnaire was designed in line with the objective of the study which is to examine factors influencing consumer choice of brands of custard in Enugu State. To make for good responses in the study, convenience sampling technique was adopted in administering the questionnaire to the respondents.

The data collected were presented and analyzed with descriptive and inferential statistics, while the corresponding hypotheses were tested with simple linear regression and Pearson correlation with the aid of computer through the application of Statistical Package for Social Sciences (SPSS). Topman's formula for an infinite population as cited by Nwbuokei (1986), with 95\% degree of freedom at 5\% error tolerance was used in determining the sample size

$$
\begin{gathered}
\mathrm{n}=\mathrm{Z}^{2} \mathrm{PQ} \\
\mathrm{e}^{2}
\end{gathered}
$$

Where $\mathrm{n}=$ sample size

$\mathrm{Z}$ = confidence level (1.96) Constant

$\mathrm{P}=$ proportion of positive response 7 (or 70\%)

$\mathrm{Q}=$ proportion of negative response 3(or 30\%)

$\mathrm{e}=$ Error margin

$\mathrm{n}=1.962(0.7 \times 0.3)$

$$
(0.05)^{2}
$$

$$
=\frac{3.8416 \times 0.21}{0.0025}=\frac{0.806736}{0.0025}
$$

$=322.6944$ 
Approximately 323

The sample size is 323

Three hundred and twenty-three copies of the questionnaire were administered. 303 copies were duly completed and returned while 20 copies were not properly completed and returned.

\section{Data Analysis, Result And Discussion}

Table1: Coded Responses on Price and Consumers Choice of Brands of Custard in Enugu State

\begin{tabular}{|l|l|l|l|l|l|l|l|l|}
\hline S/No & \multicolumn{1}{|c|}{ Questionnaire items } & \multicolumn{2}{c|}{$\begin{array}{c}\text { S. Agree/ } \\
\text { Agree }\end{array}$} & \multicolumn{2}{l|}{ Undecided } & \multicolumn{2}{c|}{$\begin{array}{c}\text { Disagree/ } \\
\text { S. Disagree }\end{array}$} & \\
\hline & & Freq & $\%$ & Freq & $\%$ & Freq & $\%$ & Total (Freq) \\
\hline 1. & The price of custard affects its demand & 282 & $93 \%$ & 8 & $3 \%$ & 13 & $4 \%$ & 303 \\
\hline 2. & $\begin{array}{l}\text { Custard has different brands and it } \\
\text { affects consumer choice of patronage. }\end{array}$ & 274 & $90 \%$ & 12 & $4 \%$ & 17 & $6 \%$ & 303 \\
\hline & Total & 556 & & 20 & & 30 & & 606 \\
\hline
\end{tabular}

Source: Field Survey, 2018

According to the table (1) based on aggregate response $556(92 \%)$ indicated strongly agree and agreed, $20(3 \%)$ indicated undecided while $30(5 \%)$ indicated disagree and strongly disagree. This implies that price has an effect on Consumers Choice of Brands of Custard in Enugu State.

Table2: Result of the effect of Price on consumer Choice of Brands of Custard in Enugu State

\begin{tabular}{|c|c|c|c|c|c|c|c|c|}
\hline \multirow[t]{2}{*}{ Particulars } & \multirow[t]{2}{*}{$\mathbf{R}$} & \multirow[t]{2}{*}{$\mathbf{R}^{2}$} & \multirow[t]{2}{*}{ Adj.R $\mathbf{R}^{2}$} & \multirow[t]{2}{*}{ DW } & \multicolumn{2}{|c|}{ Standard Coefficient } & \multirow[t]{2}{*}{$\mathbf{F}$} & \multirow[t]{2}{*}{ Sig } \\
\hline & & & & & Beta & T. value & & \\
\hline Consumers choice & 0.950 & 0.902 & 0.901 & 0.382 & 0.950 & 52.580 & 2764.649 & 0.000 \\
\hline
\end{tabular}

Source: SPSSWIN 15:00 Version

$\mathrm{R}=$ Correlation coefficient of Beta

$\mathrm{R}^{2}=$ Coefficient of Determination

Adj. $R^{2}=$ Adjusted Coefficient of Determination

DW= Durbin- Watson (d) test statistic

$\mathrm{T}-$ Value $=$ Student $\mathrm{t}-$ test statistics

$\mathrm{F}=\mathrm{F}=$ test statistics

Model Equation $=0.438+0.904$

The result indicates that price has a positive effect on consumer choice as $\mathrm{t}=52.580$ which is above the rule of thumb positivity of 2 and coefficient of price (0.438). The variations from the model as indicated by the coefficient of determination $\left(\mathrm{R}^{2}\right)$ value of 0.902 .

Also, the result shows that there is a positive relationship between price and consumer choice as indicated by R-value of 0.950 which is the same with the value of Beta 0.950 .

Table3: Coded Responses on Packaging and Consumers Choice of Brands of Custard in Enugu State

\begin{tabular}{|l|l|l|l|l|l|l|l|l|}
\hline S/No & \multicolumn{1}{|c|}{ Questionnaire items } & \multicolumn{2}{|c|}{$\begin{array}{c}\text { S. Agree/ } \\
\text { Agree }\end{array}$} & \multicolumn{2}{|c|}{ Undecided } & \multicolumn{2}{c|}{$\begin{array}{l}\text { Disagree/S. } \\
\text { Disagree }\end{array}$} & \\
\hline & & Freq & $\%$ & Freq & $\%$ & Freq & $\%$ & $\begin{array}{l}\text { Total } \\
(\text { Freq })\end{array}$ \\
\hline 1. & $\begin{array}{l}\text { Well packaged custards attracts } \\
\text { patronage }\end{array}$ & 291 & $96 \%$ & 5 & $2 \%$ & 7 & $2 \%$ & 303 \\
\hline 2. & $\begin{array}{l}\text { The packaging of custard makes it look } \\
\text { more attractive and marketable. }\end{array}$ & 289 & $95 \%$ & 3 & $1 \%$ & 11 & $4 \%$ & 303 \\
\hline & Total & 580 & & 8 & & 18 & & 606 \\
\hline
\end{tabular}

Source: Field survey 2018

According to the table (3) based on the aggregate response, $580(96 \%)$ indicated strongly agree and agreed, $8(1 \%)$ indicated undecided. While $18(3 \%)$ indicated disagree and strongly disagree. This implies that packaging has positive influence on consumer choice of brands of custard in Enugu State. 
Table4: Descriptive Statistics of the Relationship between packaging and Consumer Choice of Brands of Custard in Enugu State

\begin{tabular}{|l|l|l|l|}
\hline & \multicolumn{1}{|c|}{ Mean } & \multicolumn{1}{|c|}{ Std. Deviation } & N \\
\hline Packaging & 4.5908 & .70301 & 303 \\
\hline Consumers choice & 4.5941 & .76138 & 303 \\
\hline
\end{tabular}

Source: SPSSWIN 15:00 Version

Table5: Correlation between Packaging and Consumer Choice of Brands of Custard in Enugu State

\begin{tabular}{|l|l|l|l|}
\hline \multicolumn{2}{|l|}{} & Packaging & \multicolumn{1}{c|}{ Consumer choice } \\
\hline \multirow{4}{*}{ Packaging } & Pearson Correlation & 1 & $.957(* *)$ \\
\cline { 2 - 4 } & Sig.(2 tailed) & & .000 \\
\cline { 2 - 4 } & $\mathrm{N}$ & 303 & 303 \\
\hline \multirow{3}{*}{ Consumers choice } & Pearson Correlation & $.957(* *)$ & 1 \\
\cline { 2 - 4 } & Sig.(2tailed) & .000 & \\
\cline { 2 - 4 } & $\mathrm{N}$ & 303 & 303 \\
\hline
\end{tabular}

Source: SPSSWIN 15: Version

Table 5 shows the descriptive statistics of the relationship between packaging and consumers choice, with a mean of 4.5908 and a standard deviation of .70301 for packaging and a mean response of 4.5941 and standard deviation of .76138 for consumer choice. By careful observation of standard deviation of standard deviation values, it can be said there is about the same variability of data points amongst the dependent and independent variables.

Table 5 is the Pearson correlation matrix of the relationship between packaging and consumers choice, showing the correlation coefficient, significant values and the number of cases. The correlation coefficient shows 0.957 ; this value indicates the correlation is significant at 0.05 level (2tailed) and implies that there is a positive relationship between packaging and consumers choice $(\mathrm{R}=0.957)$. However, the computed correlation coefficient is greater than the table value of $\mathrm{R} 0.098$ with 301 degrees of freedom $(\mathrm{df}=\mathrm{n}-2)$ at an alpha level for a two- tailed test $(\mathrm{R}=0.957 ., \mathrm{p}<.05)$. This result indicates that packaging has positive influence on consumer choice of brands of custard in Enugu Metropolis. Hence, the null hypothesis should be rejected.

Table 6: Coded Responses on Advertising and consumer choice of brands of custard in Enugu State

\begin{tabular}{|l|l|l|l|l|l|l|l|l|}
\hline S/No & \multicolumn{1}{|c|}{ Questionnaire items } & \multicolumn{2}{|c|}{$\begin{array}{c}\text { S. Agree/ } \\
\text { Agree }\end{array}$} & \multicolumn{2}{|l|}{ Undecided } & \multicolumn{2}{c|}{$\begin{array}{c}\text { Disagree/S. } \\
\text { Disagree }\end{array}$} \\
\hline & & Freq & $\%$ & Freq & $\%$ & Freq & $\begin{array}{l}\% \\
\text { Total } \\
\text { (Freq) }\end{array}$ \\
\hline 1. & I buy custard that can be easy to find & 275 & $91 \%$ & 9 & $3 \%$ & 19 & $6 \%$ & 303 \\
\hline 2. & I love my favorite custard because of its adverts & 280 & $92 \%$ & 8 & $3 \%$ & 15 & $5 \%$ & 303 \\
\hline & Total & 555 & & 17 & & 34 & & 606 \\
\hline
\end{tabular}

Source: Field survey 2018

According to the table (6) based on the aggregate response, 555 (91\%) indicated strongly agree and agree, $17(3 \%)$ indicated undecided. While $34(6 \%)$ indicated disagree and strongly disagree. This implies that advertising has a significant effect on consumer choice of brands of custard in Enugu State.

Table7: Result of the effect of Advertising on consumer choice of Brands of Custard in Enugu State

\begin{tabular}{|c|c|c|l|l|l|l|l|c|}
\hline Particulars & $\mathbf{R}$ & $\mathbf{R}^{2}$ & Adj.R & \multirow{2}{*}{ DW } & \multicolumn{2}{|c|}{$\begin{array}{c}\text { Standard } \\
\text { Coefficient }\end{array}$} & F & Sig \\
\cline { 6 - 7 } & & & & & Beta & T. value & & \\
\hline Consumers choice & 0.947 & 0.896 & 0.896 & 0.320 & 0.947 & 50.923 & 2593.126 & 0.000 \\
\hline
\end{tabular}

Source: SPSSWIN 15:00 Version

$\mathrm{R}=$ Correlation coefficient of Beta

$\mathrm{R}^{2}=$ Coefficient of Determination

Adj. $R^{2}=$ Adjusted Coefficient of Determination

DW= Durbin- Watson (d) test statistic 
$\mathrm{T}-$ Value $=$ Student $\mathrm{t}$ - test statistics

$\mathrm{F}=\mathrm{F}=$ test statistics

Model Equation $=0.121+1.031$

The result shows that Advertising has a significant effect on consumers choice as $t=50.923$ which is above the rule of thumb positivity of 2 and coefficient of the advertising $(0.121)$. The variations from the model are explained by the model as indicated by the coefficient of the determination $\left(\mathrm{R}^{2}\right)$ value of 0.896

There is a strong relationship between advertising and consumers choice as indicated by R-value of 0.947 which is the same with the value of Beta 0.947 .

\subsection{Discussion of Findings}

The results show that:

- Price had a positive effect on consumer choice of brands of custard in Enugu State. (R value of $0.950 ; t=52.580 ; \mathrm{SP}<0.05)$. The finding is in line with the finding of Adede \& Kinoti (2016) who found out that price is significant in influencing choice of milk brands in Eastlands

- Packaging had a positive influence on consumer choice of brands of custard in Enugu State (R $=0.957, \mathrm{p}<.05)$. This finding is in line with the finding of Ahmed et al (2014) that packaging elements like its Colour, Packaging material, design of wrapper and innovation are more important factors when consumers are making any buying decision. This equally agrees with the finding of Kunle et al (2012), that packaging is significantly recognized as a source of product information; consumers are aware that packaging carries product information; consumers employ packaging information to make purchase decision, and consumers considers a given number of items of information adequate in making purchase decisions.

- Advertising had a significant effect on consumer choice of Brands of Custard in Enugu State (R value of $0.947 ; \mathrm{t}=50.923$; SP < 0.05). This finding is in agreement with the finding of (Shamout, 2016) which states that advertisingal tools are playing an important role to stimulate customers towards buying any promoted product and that will definitely increase dealers and retailers profit and market share.

\section{CONCLUSION}

The study concludes that there is a significant relationship between price, packaging, advertising and consumer choice of custard brands in Enugu State. The reason for the above deduction hinges on the result of the three hypotheses. The three factors influencing of consumer choice of custard brands have positive effects on choice of the consumers.

\section{RECOMMENDATIONS}

Based on the findings and the conclusion of the study,the following recommendations were made:

- Manufacturers should consider the effect of price on choice of custard and also activities of the competitors in order to gain the market share and retain customers' choice

- There should be adequate advertisement of custard brands both in urban and rural areas. This will help consumers in those areas to know that such brands are in existence.

- Producers of custard brands should consider consumers choice before producing their brand. The idea will encourage patronage from consumers and also help to reduce waste.

\section{REFERENCES}

[1] Abah, A. D., \& Olohiliye, A. P. (2015). Analysis of the effect of advertising on sales volume of an agroallied company: A case of Benue Brewery Limited, Makurdi, Benue State, Nigeria. American Journal of Economics, Finance and Management, 1(5), 473-481.

[2] Abubakar, H. S. (2014). Impact of marketing communication on financial performance of banks: Aa study of First Bank of Nigeria PLC. Research Journal of Finance and Accounting, 5(24), 139-147.

[3] Ahmed, I. R., Parmar,V., \& Amin, M. A. (2014). Impact of product packaging on consumer's buying behavior. European Journal of Scientific Research, 120(2), 145-157. 
[4] Adede, A. O., \& Kinoti, M.W. (2016). Determinants of consumer's choice of milk brands in selected residential estates owned by Nairobi City County, Kenya, International Journal of Business and Social Science, 7(4).

[5] Alex, S. P. \& Menon S. S. (2013). Factors influencing buyer behaviour in FMCG. Journal of Business and Management, 2(2), 21-33.

[6] Ayuba, B. (2014). Assessment of factors influencing consumer satisfaction: A survey of customers of Nigerian manufacturing companies, World Review of Business Research 4(3), 148-161.

[7] Barry, T. E. \& Howard, D. (1990). A review and critique of the hierarchy of effects in Advertising, International Journal of Advertising, 9, 121-135.

[8] Belch, G. E., \& Belch, M. A. (2018). Advertising and promotion-an integrated marketing communications perspective (11th ed.). New York: Irwin/McGraw Hill.

[9] Bondari, B. (2010). World press 2.9 E- commerce: Build a Proficient on line store to sell products and services, from Technologies to Solutions. Birmingham- Mumbai. Packet Publishing.

[10] Bridges, E., Briesch. R. A., \& Yim, C. K. (2006). Effects of prior brand usage and advertising on consumer advertising response. Journal of Retailing, 82(4), 295-307.

[11] Brisech, R., Krishna, A., Lehman D. R., \& Yuan, H. (2002). A Meta- analysis of the impact of price presentation on perceived savings. Journal of Retailing, 78,101-118.

[12] Brosekhan, A. A., \& Velayutham, C. M. (2013).Consumer buying behavior: A literature. Journal Review of Business and Management (10SR-JBM), 23(19), 8-16.

[13] Callwood, K. (2013).Psychological Factors that Influence Consumer Buying Behaviour: Retrieved from http://www.ehow.com, Psychological- Influence-Consumer Buying Behaviour html.

[14] Cook, S. \& Mathur, U. C. (2008). Customer care excellence: How to create an effective customer Focus, 5th ed. Kogan Page.

[15] Damlola, A. O. \& Njogo, B. O. (2012). The effect of consumer behaviour and attitudinal tendencies towards purchase decision (A case study of Unilever Nigeria Plc ,Cadbury Nigeria Plc, United African Companies Plc.). Arabian Journal of Business and Management Review 1 (12).

[16] Dawson, J., Findlay, A. \& Sparks, L. (2006). The Retailing reader. London: Routledge.

[17] Deliya, M. M. \& Parmar, B. (2013). Role of packaging on consumer buying behaviour- patan district. Global Journal of Management and Business Research 12 (10): 49-67.

[18] Domie, S. P. (2013). .Assessing the factors influencing consumer switch from local to imported products, A Case Study of Kasapreko Company Limited Ghana. Degree Programme in International Business.

[19] Doyle, C. (2002). Market Definitions and dominance, ITU, competition policy workshop, Geneva.

[20] Durmaz, Y. (2014). The Impact of psychological factors on consumer buying behaviour and an empirical application in Turkey. Asian Social Sciences, 10(6), 194-204.

[21] Engel, J. F. \& Black, R. D. (1968). Consumer behaviour. Hinsdale 111: Dryden Press

[22] Enwere, N. J. (1998). Foods plants origin. Afro-Obis Publications, Ltd., Nsukka

[23] Feinberg, R. A. (1986). Credit cards as spending facilitating stimuli: A conditioning interpretation. Journal of Consumer Research, (13), 348-356.

[24] Gilaninia, S., Taleghani, M., \& Azizi, N. (2013). Marketing mix and consumer behaviour. Kuwait Chapter of Arabian Journal of Business Management Review, 2(12), 53-58.

[25] Hawkins, D. I, Best, R. J. \& Coney, K. A. (1998). Consumer behaviour: Building marketing strategy, New York: McGraw- Hill Higher Education.

[26] Howard, J. A. \& Sheth, J. N. (1969). The theory of buyer behaviour. New York: John Wiley.

[27] Ihekoronye, A. I. \& Ngoddy, P. O. (1985). Integrated food science and technology for the tropics. London: Macmillan Publishers Ltd.

[28] Joshi, D. (2013). Effective of branding on buying behaviour, The macro theme Review, 2 (7): 156-159.

[29] Kardes, F, Cronley, M., \& Cline, T. (2008). Consumer behaviour. South-western, Cengage Learning.

[30] Khan, M. (2004). Consumer behaviour, 2nd ed. New Delhi:, New Age International Publishers

[31] Khasawneh, K. \& Hasouneh, A. B. I. (2010). The effect of familiar brand names on consumer behaviour: A Jordanian perspective. International Research Journal of Finance and Economics, (3): 33-57.

[32] Kotler, P., Armstrong, G., \& Opresnik, M. O. (2018). Principles of marketing (17th ed: global ed). UK: Pearson Education Ltd.

[33] Kotler, P. (2003). Marketing management, 11th edition; Englewood Cliffs: Prentice-Hall Inc.

[34] Kotler, P., \& Armstrong, G. (1996). Principles of marketing, Translates Ali Parasaeian, Tehran, Press Adabestan. 
[35] Kotler, P., \& Armstrong, G. (2012). Principles of marketing (14th ed.). New Jersey: Pearson Education Ltd.

[36] Kumar, A., \& Babu, S. (2014). Factors influencing consumer buying behaviour with special reference to dairy products in Pondicherry State, Journal of Research in Management and Technology, (3), 1-9.

[37] Kunle, L. P. \& Ganiyu, R. A (2012). Packaging and the incidence of information overload in a low- risk market: A Study of Grocery Products, European Journal of Business and Social Sciences, (10), 61-72.

[38] Ladipo, P. K. A. \& Olufayo, T. O. (2011). The multiple roles of packaging in the entire marketing process channel of distribution and consumer perspective. International Journal of Business Administration, 2(4), 181-184.

[39] Lamb, C. W., Hair, J. F. \& McDaniel, C. (2011), MKTD Student Edition, South Western: Mason.

[40] Lawan, A. L., \& Zanna, R. (2013). evaluation of socio- cultural factors influencing consumer buying behavior of clothes in Borno State Nigeria, International Journal of Basics and Applied Sciences, 1, (3) :519-529.

[41] Lindsay, W. M., \& Evans, J. R. (2011). The management and control of quality, 8th, South - Western: Cengage Learning.

[42] Lukuman, A. O. (2013). Consumer purchasing behaviour: A study of Etisalat Nigeria. Degree Programme. Finland: Seinäjoki University

[43] Malik, M. E., Ghafor, M. M., Igbal, H. K., Ali, Q, Hunbal, H., Noman, M. \& Ahmad, B. (2013). impact of brand image and advertisement on consumer buying behaviour. World Applied Sciences Journal, 23 (1), 117-122.

[44] Marsden, D., \& Littler, D. (1998). Positioning alternative perspectives of consumer behaviour. Journal of Marketing Management, (14), 3-28

[45] Marero, L. M., Payumo, E. M., Aguinaldu, A. R. \& Homma, S. (1988). Nutritional characteristics of weaning food prepared from germinated cereals and legumes. Journal of Food Science, (53), 13991402.

[46] Miebaka, D.G., Nwiepe, N. M. \& Kpunee H. N. (2017). Consumer behavioural pattern and patronage of made in nigeria bags: A survey of bags producers in Rivers State, Nigeria, IIARD International Journal of Economics and Business Management, 3(2), 10-16.

[47] Modi, S., \& Jhulka, T. (2012). Consumer buying behaviour: Changing shopping patterns. International Journal of Business Management, 3(3),: 527-530

[48] Nagar, K. (2009). Evaluating the effects of consumer sales on brand loyal and brand switching segments. VISSION- Journal of Business Perspective, 13(4), 35-48.

[49] Nicosia, F. M. (1966). consumer decision processes, Englewood Cliff N.J: Prentice Hall Inc

[50] Nwabuokei, P. (1986). Fundamentals of Statistics, Enugu: Koruna Publications

[51] Okolo, V. O., Mmamel, Z. U., Nmere, O. N., Nduka, C., Obikeze, C. O., \& Oranusi, I. N. (2018). Impact of online advertising on the profitability of Ecobank Nigeria Plc. International Journal of Research in Finance and Marketing, 8(8), 35-50.

[52] Okoye, J. I., Nkwocha, A. C. \& Agbo, A. O., (2008). Nutrient composition and acceptability of soyfortified custard, Continental J. Food Science and Technology 2, 37-44.

[53] Oni, E. O., \& Bananda, R. A. (2010). Marketing: Principle practices and issues, Ibadan: Ejon Publishers Limited.

[54] Purwanto, G. A. (2013). Analysis of consumer behaviour affecting consumer willingness to buy in 7 eleven convenience store. Universal Journal of Management, 1(2), 69-75.

[55] Raban, S. W. (2010). Bio- based packaging- application in meat industry.

[56] Rani, P. (2014). Factors influencing consumer behaviour, Int.J.Curr Res. Aca. Rev 2 (9), 52-61.

[57] Schiffman, K. (2001). Consumer behavior. 2nd Edition, Australia: Pearson Education.

[58] Shabgou, M., \& Daryani, S. M. (2014). Towards the sensory marketing: Stimulating the five senses (sight, hearing, smell, touch and taste) and its impact on consumer behaviour. Indian Journal of Fundamental and Applied Life Sciences, 4(1), 573-581.

[59] Shah, S., Ahmad, A., \& Ahmad, N. (2013). Role of packaging in consumer buying behaviour, International Review of Basic and Applied Sciences, 1(2). 35-41.

[60] Shamout, M. D. (2016). The impact of promotional tools on consumer buying behavior in retail market, International Journal of Business and Social Science, 7(), 75-85.

[61] Sinebe, J. E., Okonkwo, U. C., \& Enyi, L. C. (2014). Simplex optimization of production mix: A case of custard producing industries in Nigeria. International Journal of Applied Science and Technology, 4(4), 180-189. 
[62] Singh, A. \& Singh, V. (2014). Factors affecting buying behaviour of rural consumers. International Journal of Management and Social Sciences Research, 3(8). 8-12.

[63] Solomon, M. (1996). Consumer behavior: Buying, having and being, 3rd Edition New Jersey: Prentice Hall Inc.

[64] Solomon, M., Marshall, G., \& Staurt E. (2008). Marketing: Real people, real choice, $5^{\text {th }}$ edition, New Jersey: Pearson Education Inc.

[65] Srivastava, S. (2013). Factors affecting buying behavior of consumers in unauthorized colonies for FMCG products, Global Journal of Management and Business Studies, 3(7), 785-792.

[66] Sternthal, B. \& Criag, C. S. (1982). Consumer behaviour: An Information-Processing perspective, Prentice-Hall, Engelwood Cliffs.

[67] Ugonna, I. A., Ndubisi, E. C., Otugo, N. E., Eze, P. C., \& Akabogu, O. C. (2014). Anatomical effects of billboard advertising on consumers' purchase intent of beer. International journal of Innovative Research in Management, 3(7), 14-24.

[68] Yu-Jui, L. (2012). Consumer behavior on smart phone, major in business administration, graduate school of commerce.

[69] Zia \& Shahzad (2015). Role of advertising on sale's performance: A case study of bata \& service shoes (Okara). International Journal of Management, Accounting and Economics, 2(1), 37-45.

Citation: Okoro, Deborah P, et.al. "Factors Influencing Consumer Choice of Brands of Custard in Enugu State" International Journal of Managerial Studies and Research (IJMSR), vol 7, no. 11, 2019, pp. 38-51. doi: http://dx.doi.org/10.20431/2349-0349.0711005.

Copyright: (c) 2019 Authors. This is an open-access article distributed under the terms of the Creative Commons Attribution License, which permits unrestricted use, distribution, and reproduction in any medium, provided the original author and source are credited. 